\title{
Asthma and rhinitis symptoms in individuals from different socioeconomic levels in a Brazilian city
}

\author{
Tiana Baqueiro, M.Sc., ${ }^{\ddagger}$ Lain Pontes-de-Carvalho, M.D., Ph.D.,§I \\ Fernando Martins Carvalho, M.D., Ph.D.,\# Nilza Maria Santos, M.Sc., Medical Student's Group, and \\ Neuza Maria Alcântara-Neves, M.D., Ph.D.*§ (Brazil)
}

\begin{abstract}
Allergy is considered to be caused by complex interactions between genetic and environmental factors. Socioeconomic status (SES) may be the most important environmental determinant of allergy because it determines the living environment, but few studies have addressed the causal role of SES in allergy. The aim of this study was to compare the prevalence of asthma and rhinitis symptoms in two SES groups in a Brazilian city. History of asthma and rhinitis symptoms was collected using the International Study of Asthma and Allergies in Childhood questionnaire. SES was determined by the Gallup method. Sera from subgroups of the individuals were used to determine total, anti-Dermatophagoides pteronyssinus and anti-Blomia tropicalis IgE. The prevalence of asthma

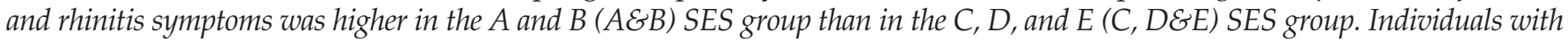
asthma and/or rhinitis were more frequently positive for anti-B. tropicalis and ant $i-\mathrm{D}$. pteronyssinus IgE than individuals without these symptoms. A positive association between total IgE levels and asthma and rhinitis symptoms was observed in the AEB SES group but not in the C, DEE SES group. Women reported more respiratory symptoms than men. These results revealed higher prevalence rates of asthma and rhinitis symptoms in individuals with higher SES and may provide support for the hygiene hypothesis, which attributes the high prevalence of respiratory allergies observed in individuals from developed countries to a low exposure to pathogens. The observed higher prevalence of asthma and rhinitis symptoms in women than in men could be attributed to differences in the perception of these symptoms or in exposures to allergens and protective pathogens.
\end{abstract}

(Allergy Asthma Proc 28:362-367, 2007; doi: 10.2500/aap.2007.28.2967)

Key words: Prevalence, asthma, rhinitis, IgE, Blomia tropicalis, Dermatophagoides pteronyssinus, socioeconomic level, allergy and gender

$\mathbf{R}$ espiratory allergies are common in many areas of the world and asthma and rhinitis are, indeed, the commonest chronic diseases in children of developed countries. ${ }^{1}$ Asthma and rhinitis can have different etiologies; the type 1 hypersensitivity reaction plays the central role in their pathogenesis (see ${ }^{\text {Ref. } 2}$ for review). The "International Study of Asthma and Allergies in Childhood" (ISAAC) program ${ }^{3}$ and others ${ }^{4}$ reported the prevalence of asthma symptoms to be higher in developed countries than in some developing countries, and that the highest and lowest rates were found in Scotland (36.7\%) and India (1.6\%), respectively. Strachan ${ }^{5}$ found lower

\footnotetext{
*Instituto de Ciências da Saúde, \#Faculdade de Medicina, Universidade Federal da Bahia, Bahia, Brazil, §Centro de Pesquisa Gonçalo Moniz, Fundação Oswaldo Cruz, Salvador, Brazil, and IIEscola Baiana de Medicina e Saúde Pública, Fundação Baiana para Desenvolvimento das Ciências, Salvador, Brazil

Supported in part by the Alergofar-Farmácia de Alergia e Cosmética, Ltda

Members of the Medical Students' Group who are coauthors of this work: Igor Sandes, Leandro Gouveia, Luis D. Sobreira Cerqueira, Manuel Lessa Ribeiro Neto, Marcelo Barbetta, Mariana Costa, Marina Lordelo, Marzio A. D'Lippi Filho, Monaliza Cunha, Paula Ferreira, Rafael Valadares, Ricardo Souza, Ricardo Heinzelmann, Samuel Juncal, Vitor Borges, Wilson Bastos Filho, and Zilda Maria Braid

Address correspondence and reprint requests to Neuza Maria Alcântara-Neves, M.D., Ph.D., Instituto de Ciências da Saúde, Universidade Federal da Bahia, Avenida Reitor Miguel Calmon, sem $n^{\circ}$, Canela, CEP-40110-100, Salvador, Bahia, Brazil E-mail address: neuza@ufba.br

Copyright (C) 2007, OceanSide Publications, Inc., U.S.A.
}

prevalence rates of asthma and atopy in farmers compared with urban inhabitants. These findings led to the formulation of the hygiene hypothesis, which attributed the decreased prevalence of allergic diseases in developing countries and in rural areas of industrialized countries to the high exposure to pathogens, and the high prevalence of allergy in developed countries to cleanness and low environmental pathogen burden.

Reported data on the relationship between socioeconomic status (SES) and atopy and/or allergic illnesses are controversial (see ${ }^{\text {Ref. } 6}$ for review). Although some authors $^{7-9}$ have found the highest asthma morbidity and prevalence rates in less affluent minority communities, others authors ${ }^{10-11}$ have found higher asthma prevalence rate in wealthier population groups, and the majority of these studies has been done in developed countries. In this study we report the prevalence of asthma and rhinitis symptoms in individuals from two SES groups and the levels total and specific antiDermatophagoides pteronyssinus and anti-Blomia tropicalis IgE in subgroups of the studied individuals.

\section{MATERIALS AND METHODS}

\section{Study Population}

Two SES groups in the city of Salvador, Bahia, Brazil, were investigated: an upper and upper-middle class 
group, composed of 228 individuals from 53 medical students' families, with socioeconomic status A or B (A\&B SES group) and a group composed by 211 individuals from 48 low-income families, with socioeconomic status $\mathrm{C}, \mathrm{D}$, or $\mathrm{E}$ (C, D\&E SES group). The families of the C, D\&E SES group usually were selected because one of their members worked in a medical student home or building. The two groups were homogeneous in relation to age and sex. SES was determined by the Gallup method. This method is based on the parents' educational levels and home characteristics such as total room number and number of bedrooms, bathrooms, TVs, refrigerators, freezers, cars, etc. Histories of asthma and rhinitis symptoms were obtained using the phase-I International Study of Asthma and Allergies in Childhood (ISAAC) questionnaire. Each student filled out the questionnaire of one family from the A\&B SES group and one family from the $C, D \& E$ SES group. Individuals who had episodes of wheezing and dry cough in the last year were considered positive for asthma. Individuals with sneezing and running nose in the last year were considered positive for rhinitis. Blood was taken from two subgroups of volunteers from both subject groups: 34 with history and 27 without history of respiratory symptoms. The work was approved by the Ethical Committee on Research of the Oswaldo Cruz Foundation, Salvador, Bahia, Brazil. Informed written consent was obtained from all study participants.

\section{ELISA for Total, Anti-B. tropicalis, and Anti-D. pteronyssinus IgE}

Total IgE was detected by capture ELISA using wells of flat-bottom polystyrene plates (COSTAR 3590, Flat Bottom, polystyrene; Costar, Cambridge, MA) containing nitrocellulose disks (Bio-Rad Laboratories, Hercules, CA), sensitized with $4 \mu \mathrm{g} / \mathrm{mL}$ of an human anti-IgE antibody (Pharmingen, San Diego, CA). Plates were blocked with $0.15 \mathrm{M}$ of phosphate-buffered saline (PBS), pH 7.2, containing 20\% of dried skimmed milk (DSM) and $0.05 \%$ of Tween 20 (Sigma, St. Louis, MO) overnight, at $4{ }^{\circ} \mathrm{C}$. Sera were diluted 1:10 in PBS containing $10 \%$ of DSM and $0.05 \%$ of Tween 20 and incubated overnight at $4^{\circ} \mathrm{C}$. A goat anti-human IgE-peroxidase conjugate (Sigma) and an anti-goat immunoglobulin-peroxidase conjugate (Dako A/S, Glostrup, Denmark) were diluted at 1:2000 and 1:10.000, respectively, and incubated for 60 minutes at room temperature. An antigen concentration curve was obtained by using human IgE (Research Diagnostics, Inc., Flanders, NJ).The results were expressed in International Units (IU). A pool of allergic patients' sera with positive prick test for dust mites was used as positive control. Umbilical cord serum from a nonatopic mother was used as a negative control. Anti-D. pteronyssinus and anti-B. tropicalis IgE were de- tected by commercial ELISA kits (DPC, Los Angeles, CA). Sera with results above $0.35 \mathrm{kU} / \mathrm{L}$, as determined by the manufacturer's instructions, were considered positive.

\section{Statistical Analysis}

Data were analyzed with the use of the EPI-INFO and the Statistical Package for the Social Sciences Computer Program (2001; SPSS, Chicago, IL). The chisquare test for linear trend in proportions was used to analyze the variation of the prevalence of asthma and rhinitis symptoms according to the socioeconomic level. The chi-square test with the Yates' correction was used to test the associations between study group and asthma and rhinitis symptoms, sex, and age. For all of the analysis, values of $p<0.05$ were considered statistically significant.

\section{RESULTS}

\section{The Prevalence of Asthma and Rhinitis Symptoms Differs in the Individuals of the Two Socioeconomic Groups}

The ISAAC questionnaire was applied to 228 individuals from the A\&B SES group and 211 individuals from the $C, D \& E$ SES group. The two groups were similar with respect to age and sex. Although the A\&B SES group consisted mainly of families of socioeconomic level A and B, the C, D\&E SES group consisted of families of socioeconomic level C, D, and E (Table 1). Forty-four percent of individuals from the A\&B SES group and $32.4 \%$ individuals from the $C, D \& E$ SES group had asthma and rhinitis symptoms $(p<0.01)$. The prevalence of asthma was $21.1 \%$ in the A\&B SES group and $12.1 \%$ in the C, D\&E SES group $(p<0.01)$. Rhinitis also was more prevalent in individuals from the first group $(32.5 \%)$ than from individuals from the second group (18.8\%; $p<0.001$; Table 2$)$. A positive association was observed between social classes and history of asthma and/or rhinitis in individuals from the C, D\&E SES group (classes C, D and E; Fig. 1) but not the A\&B SES group (classes A and B). Symptoms of asthma and/or rhinitis were more frequent in women than men in the whole population studied $(43.3 \%$ versus $29.2 \%$, respectively; $p<0.004)$ and within the A\&B SES group $(p<0.05)$ and the C, D\&E SES group $(p<$ 0.03; Table 3).

\section{High Level of Total Blood IgE Is Associated with Asthma and Rhinitis Symptoms Only in the Individuals from the A\&B SES Group}

Sera from 35 individuals suffering from asthma and rhinitis symptoms and from 26 normal individuals were examined for total IgE concentration. Total IgE concentrations were markedly higher among individuals with a clinical history of asthma and/or rhinitis in the A\&B SES group. This association was not observed 
Table 1 Characterization of the studied groups

\begin{tabular}{|c|c|c|c|c|}
\hline Variable & $\begin{array}{l}\text { A\&B SES } \\
\text { Group* } \\
(n[\%])\end{array}$ & $\begin{array}{c}\text { C, D\&E SES } \\
\text { Group\# } \\
(n[\%])\end{array}$ & $\begin{array}{l}\text { Whole Studied } \\
\text { Population } \\
(n[\%])\end{array}$ & $p$ Value $\S$ \\
\hline \multicolumn{5}{|l|}{ Sex } \\
\hline Male & $104(45.5)$ & $92(43.8)$ & $196(44.6)$ & \multirow[t]{3}{*}{0.74} \\
\hline Female & $124(54.5)$ & $119(56.2)$ & $243(55.4)$ & \\
\hline Total & $228(100.0)$ & $211(100.0)$ & $439(100.0)$ & \\
\hline \multicolumn{5}{|l|}{ Age (yr) } \\
\hline$>20$ & 107 (46.9) & $88(41.7)$ & $195(44.4)$ & \multirow[t]{3}{*}{0.31} \\
\hline$<21$ & $121(53.1)$ & $123(58.3)$ & $244(55.6)$ & \\
\hline Total & $228(100.0)$ & $211(100.0)$ & $439(100.0)$ & \\
\hline \multicolumn{5}{|c|}{ Socioeconomic status } \\
\hline A & $122(54.7)$ & $0(0)$ & $122(29.3)$ & \multirow[t]{6}{*}{$<0.0001$} \\
\hline B & $101(45.3)$ & $0(0)$ & $101(24.3)$ & \\
\hline $\mathrm{C}$ & $0(0)$ & $74(38.3)$ & $74(17.8)$ & \\
\hline $\mathrm{D}$ & $0(0)$ & 99 (51.3) & $99(23.8)$ & \\
\hline $\mathrm{E}$ & $0(0)$ & $20(10.4)$ & $20(4.8)$ & \\
\hline Total & $223(100.0)$ & $193(100.0)$ & $416(100.0)$ & \\
\hline
\end{tabular}

${ }^{*} A \mathcal{E} B$ SES group $=$ group composed of individuals with socioeconomic status $A$ or $B$.

$\# C, D E E S E S$ group = group composed by individuals with socioeconomic status $C, D$ or E.

§The chi-square test with Yates' correction was used to test the statistical differences in sex, age, and socioeconomic status distribution between the studied groups.

Table 2 Frequency of history of asthma and rhinitis symptoms according to the study groups

\begin{tabular}{|c|c|c|c|c|}
\hline \multirow{2}{*}{$\begin{array}{c}\text { Respiratory } \\
\text { Symptoms and } \\
\text { Presence }\end{array}$} & \multicolumn{2}{|c|}{ Groups } & \multirow[t]{2}{*}{ Total $n$} & \multirow[t]{2}{*}{$p^{*}$ Value } \\
\hline & $\begin{array}{c}\text { A\&B SES\# } \\
(n[\%])\end{array}$ & $\begin{array}{c}\text { C, D\&E SES } \S \\
(n[\%])\end{array}$ & & \\
\hline \multicolumn{5}{|l|}{ Asthma and rhinitis } \\
\hline Yes & $102(44.7)$ & $67(32.4)$ & 169 & \multirow[t]{2}{*}{0.01} \\
\hline No & $126(55.3)$ & $140(67.6)$ & 266 & \\
\hline \multicolumn{5}{|l|}{ Asthma } \\
\hline Yes & 48 (21.1) & $25(12.1)$ & 73 & \multirow[t]{2}{*}{0.01} \\
\hline No & $180(78.9)$ & $182(87.9)$ & 362 & \\
\hline \multicolumn{5}{|l|}{ Rhinitis } \\
\hline Yes & $74(32.5)$ & $39(18.8)$ & 113 & \multirow[t]{3}{*}{0.001} \\
\hline No & $154(67.5)$ & $168(81.2)$ & 322 & \\
\hline Total & $228(100.0)$ & $207(100.0)$ & 435 & \\
\hline
\end{tabular}

in the C, D\&E SES group (Fig. 2 A). Anti--D. pteronyssinus $\operatorname{IgE}$ was found in $77.3 \%$ of individuals with asthma and/or rhinitis and in $9.1 \%$ of individuals without asthma and/or rhinitis $(p<0.0001)$ and anti-B. tropicalis $\operatorname{IgE}$ was found in $65.0 \%$ of individuals with asthma and/or rhinitis and in $22.2 \%$ of individuals without asthma and/or rhinitis $(p<0.01$; Fig. $2, B$ and $C$ ).

\section{DISCUSSION}

In this work, high prevalence rates of asthma and rhinitis symptoms were observed in Salvador inhabitants. A study performed in a Salvador slum ${ }^{12}$ found prevalence rates of asthma and/or rhinitis similar to the rates observed in the C, D\&E SES group of this study. We found that 65.0 and $77.3 \%$ of individuals with asthma and/or rhinitis symptoms had high levels 
of anti-B. tropicalis and anti-D. pteronyssinus IgE, respectively, and Medeiros and collaborators, ${ }^{13}$ in the same city, found $57.9 \%$ of asthmatic patients with high levels of anti-D. pteronyssinus IgE antibodies. The adequacy of the ISAAC questionnaire for the identification of allergic individuals can be deduced from (1) the strong association found in this work between specific $\operatorname{IgE}$ antibodies and the histories of asthma and rhinitis symptoms and (2) the fact that the allergic individuals of this study and those studied by Medeiros and collaborators ${ }^{13}$ (hospital-based data) had similar prevalence rates of specific IgE antibodies.

A positive association between high SES was found for childhood eczema and for atopy in the United States, Italy, Britain, and East Germany. ${ }^{14-16}$ In developing countries, Addo-Yobo ${ }^{17}$ found a positive association of SES with atopy and exercise-induced bronchospasm, and Nascimento-Carvalho and collaborators ${ }^{18}$ reported that children attending a private hospital had more allergies than children attending a public hospital, who had more pneumonia. Mielck and collaborators ${ }^{19}$ stated that severe asthma is found more frequently in people of low SES than of high SES, and asthma prevalence rates, as detected in population-based works, are higher in individuals of high SES. However, several other authors did not

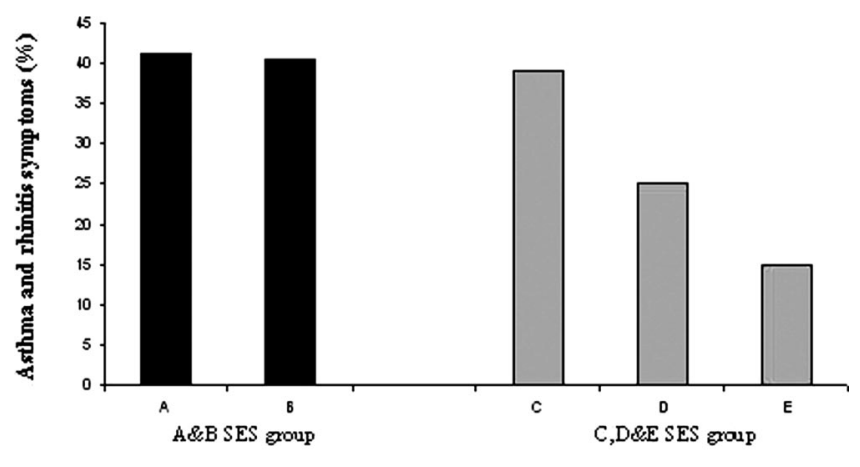

Socioeconomic berels

Figure 1. Prevalence of asthma and/or rhinitis symptoms according to socioeconomic level in the studied groups. The prevalence of asthma and/or rhinitis symptoms was correlated with socioeconomic level in 223 individuals of the AEB SES group and in 192 individuals of the $C, D \mathcal{E E}$ SES group $\left({ }^{*} p<0.01\right.$; chi-square test; test for linear trend in proportions). find significant associations between SES and prevalence of respiratory allergies. ${ }^{7-9,20}$ The association of high levels of SES and prevalence of asthma and rhinitis symptoms, found in this study, is consistent with the former authors' findings and indirectly provides support for the hygiene hypothesis.

The hygiene hypothesis ${ }^{5,21,22}$ suggested that the high burdens of viruses and intracellular bacteria, which frequently cause childhood infections in developing countries, would deviate the early childhood Th2-biased, atopy-prone immune system to a Th1 immune system, which may protect against the development of allergies. ${ }^{23-25}$ Parasites, despite inducing strong Th2type responses with production of IL-4, IL-5, and IL-13 and consequently increasing the IgE synthesis, have been reported also to provide protection against allergy. ${ }^{26-28}$ Regulatory ILs ${ }^{29,30}$ produced in the chronic phase of helminth infections could mediate protection against allergy. ${ }^{31}$ Although fecal examination for intestinal parasites were not done in all subjects of the present work, fecal samples of 90 individuals of the C, D\&E SES group were examined (unpublished data, Laboratorio de Acarologia e Alergia, 2004) and they had high prevalence of intestinal helminthes $(27.1 \%$ for Trichuris trichiura, $15.7 \%$ for Ascaris lumbricoides and $5.7 \%$ for Schistosoma mansoni).

The wealthy individuals living in developing countries have lifestyles similar to those living in developed countries. They live in areas with high standards of sanitation in clean houses; have adequate access to antibiotics and vaccination; and have reduced exposure to viral, bacterial, and helminth infections, which could, according to the hygiene hypothesis, make them more likely to develop allergies.

The finding of a positive association between high levels of IgE and asthma and rhinitis symptoms in the A\&B SES group but not in the C, D\&E SES group can be attributed to the absence of other causes of $\operatorname{IgE}$ stimulation (e.g., intestinal helminth infections) apart from environmental allergens in the former group. However, in the C, D\&E SES group, the elevated IgE levels may be attributable to both allergen- and parasite-specific IgE and therefore would be found frequently elevated in parasite-infected, nonallergic indi-

Table 3 Frequency of clinical history of asthma and rhinitis symptoms according to gender

\begin{tabular}{|c|c|c|c|c|c|c|c|c|c|}
\hline \multirow{2}{*}{$\begin{array}{l}\text { Asthma and } \\
\text { Rhinitis } \\
\text { Symptoms }\end{array}$} & \multicolumn{3}{|c|}{ Total } & \multicolumn{3}{|c|}{ A\&B SES Group } & \multicolumn{3}{|c|}{ C, D\&E SES Group } \\
\hline & $\begin{array}{c}\text { Female } \\
n(\%)\end{array}$ & $\begin{array}{c}\text { Male } \\
(n[\%])\end{array}$ & $\begin{array}{c}p \\
\text { Value }\end{array}$ & $\begin{array}{c}\text { Female } \\
(n[\%])\end{array}$ & $\begin{array}{l}\text { Male } \\
(n[\%])\end{array}$ & $\begin{array}{c}p \\
\text { Value }\end{array}$ & $\begin{array}{c}\text { Female } \\
(n[\%])\end{array}$ & $\begin{array}{c}\text { Male } \\
(n[\%])\end{array}$ & $\begin{array}{c}p \\
\text { Value }\end{array}$ \\
\hline Present & $104(43.3)$ & $57(29.2)$ & 0.004 & $62(50.8)$ & $38(36.9)$ & 0.05 & $42(35.6)$ & $19(20.6)$ & 0.03 \\
\hline Absent & $136(56.7)$ & $138(70.8)$ & & $60(49.2)$ & $65(63.1)$ & & $76(64.4)$ & $73(79.4)$ & \\
\hline
\end{tabular}

The chi-square test with Yates' correction was used to test the association between asthma and rhinitis symptoms and gender in the study groups. 


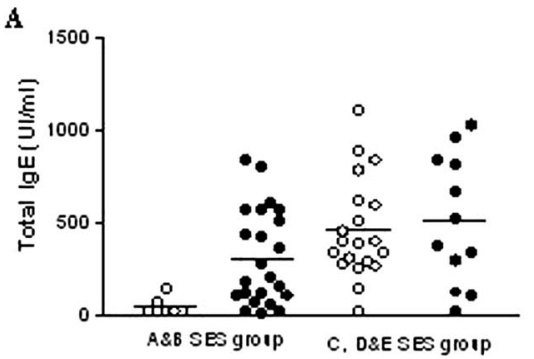

- Absence of astrma and rhinitis symptorrs

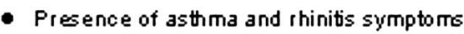

Socioeconomic levels
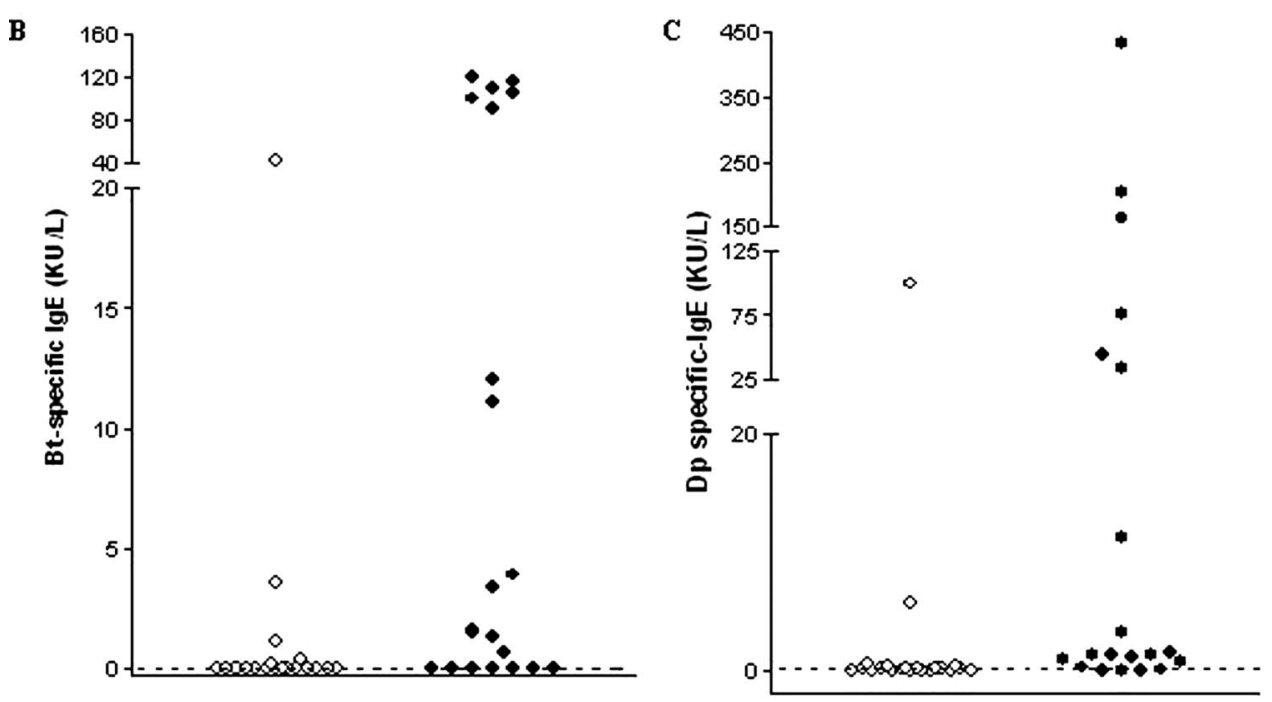

Figure 2. Total and specific IgE anti-D. peteronyssinus and B. tropicalis in subgroups of the studied groups. (A) Serum concentration of total $\operatorname{IgE}(\mathrm{IU} / \mathrm{mL})$. Lines represent the total IgE means obtained in the studied groups; (B and C) B. tropicalis- and D. pteronyssinusspecific IgE levels (kIU/L) of individuals from the studied groups according to the presence or absence of asthma and/or rhinitis symptoms. Lines represent the assay cutoff of the studied groups as recognized by the kit manufacturer (DPC).

viduals. Similar findings have already being described elsewhere. ${ }^{32-34}$

In this study, symptoms of asthma and/or rhinitis were higher in women than in men for both socioeconomic levels. Similar findings have already being reported. ${ }^{35,36}$ This finding could be attributed to a higher perception of symptoms by women than by men and/or to putative differences in exposure to allergens. Additional work should be performed in populations larger than this study to clarify these points.

\section{ACKNOWLEDGMENTS}

The authors are in debt to Luciane Souza de Jesus for the technical laboratory support and to Dr. Philip Cooper for correcting the English and critically reviewing the article.

\section{REFERENCES}

1. Wong GWK, Hui DSC, Chan HH, et al. Prevalence of respiratory and atopic disorders in Chinese schoolchildren. Clin Exp Allergy 31:1225-1231, 2001.

2. Kaliner M, Eggleston PA, and Mathews KP. Rhinitis and asthma. JAMA 258:2851-2873, 1987.

3. The International Study of Asthma and Allergies in Childhood (ISAAC) Steering Committee. Worldwide variations in the prevalence of asthma symptoms: The International Study of Asthma and Allergies in Childhood (ISAAC). Eur Respir J 12:315-335, 1998.

4. Addo Yobo EO, Custovic A, Taggart SC, et al. Risk factors for asthma in urban Ghana. J Allergy Clin Immunol 108:363-368, 2001.

5. Strachan DP. Hay fever, hygiene, and household size. BMJ 299:1259-1260, 1989.

6. Volmer T. The socio-economics of asthma. Pulm Pharmacol Ther 14:55-60, 2001.

7. Gottlieb DJ, Beiser AS, and O'Connor GT. Poverty, race, and medication use are correlates of asthma hospitalization rates. A small area analysis in Boston. Chest 108:28-35, 1995.

8. Marder D, Targonski P, Orris P, et al. Effect of racial and socioeconomic factors on asthma mortality in Chicago. Chest 101(suppl 6):426S-429S, 1992.

9. Weiss KB, and Wagener DK. Changing patterns of asthma mortality. Identifying target populations at high risk. JAMA 264:1683-1687, 1990.

10. Westerling R, Gullberg A, and Rosen M. Socioeconomic differences in "avoidable" mortality in Sweden 1986-1990. Int J Epidemiol 25:560-567, 1996.

11. Mielck A, Reitmeir P, and Wjst M. Severity of childhood asthma by socioeconomic status. Int J Epidemiol 25:388-393, 1996.

12. Medeiros JRM, Figueiredo JP, Almeida MC, et al. Prevalência de alergia respiratória em indivíduos de área endêmica de Schistosoma mansoni. Rev Bras Alerg Imunopatol 23:036, 2000. 
13. Medeiros Jr M. Sensibilização a aeroalérgenos em indivíduos portadores de asma brônquica e/ou rinite crônica em SalvadorBahia. Tese, Curso de Pós-Graduação em Medicina. Departamento de Medicina. Faculdade de Medicina. Universidade Federal da Bahia, Salvador-Bahia, 70, 1997.

14. Forastiere F, Agabiti N, Corbo GM, et al. Socioeconomic status, number of siblings, and respiratory infections in early life as determinants of atopy in children. Epidemiology 8:566-570, 1997.

15. Strachan DP, Harkins LS, Johnston ID, and Anderson HR. Childhood antecedents of allergic sensitization in young British adults. J Allergy Clin Immunol 99:6-12, 1997.

16. Heinrich J, Popescu MA, Wjst M, et al. Atopy in children and parental social class. Am J Public Health 88:1319-1324, 1998.

17. Addo Yobo EO, Custovic A, Taggart SC, et al. Exercise induced bronchospasm in Ghana: Differences in prevalence between urban and rural schoolchildren. Thorax 52:161-165, 1997.

18. Nascimento-Carvalho $\mathrm{CM}$, Rocha $\mathrm{H}$, and Benguigui $\mathrm{Y}$. Effects of socioeconomic status on presentation with acute lower respiratory tract disease in children in Salvador, Northeast Brasil. Pediatr Pulmonol 33:244-248, 2002.

19. Mielck A, Reitmeir P, and Wjst M. Severity of childhood asthma by socioeconomic status. Int J Epidemiol 25:388-393, 1996.

20. Sibbald B, and Rink E. Labelling of rhinitis and hayfever by doctors. Thorax 46:378-381, 1991.

21. Kalliomaki M, and Isolauri E. Pandemic of atopic diseases-A lack of microbial exposure in early infancy? Curr Drug Targets Infect Disord 2:193-199, 2002.

22. Varner AE. The increase in allergic respiratory diseases: Survival of the fittest? Chest 121:1308-1316, 2002.

23. Shaheen SO, Aaby P, Hall AJ, et al. Measles and atopy in Guinea-Bissau. Lancet 347:1792-1796, 1996.

24. Shirakawa T, Enomoto T, Shimazu S, and Hopkin JM. The inverse association between tuberculin responses and atopic disorders. Science 275:77-79, 1997.

25. Matricardi PM, Rosmini F, Riondino S, et al. Exposure to foodborne and orofecal microbes versus airborne viruses in relation to atopy and allergic asthma: Epidemiological study. BMJ 320: 412-417, 2000.

26. Van Den Biggelaar AHJ, Van Ree R, Rodríguez LC, et al. Decreased atopy in children infected by Schistosoma haematobium: A role for parasite-induced interleukin-10. Lancet 356:1723$1727,2000$.

27. Lynch NR, Palenque M, Hage I, and Diprisco MC. Clinical improvement of asthma after anthelminthic treatment in a tropical situation. Am J Respir Crit Care Med 156:50-54, 1997.

28. Mao Xq, Sun Dj, Miyioshi A, et al. The link between helminthic infection and atopy. Parasitol Today 16:186-188, 2000.

29. Borish L, Aarons A, Rumbyrt J, et al. Interleukin-10 regulation in normal subjects and patients with asthma. J Allergy Clin Immunol 97:1288-1296, 1996.

30. Lim S, Crawley E, Woo P, and Barnes PJ. Haplotype associated with low interleukin-10 production in patients with severe asthma. Lancet 352:113, 1998.

31. Yazdanbakhsh M, Kremsner PG, and Van Ree R. Allergy, parasites, and the hygiene hypothesis. Science 296:490-494, 2002.

32. Hagel I, Lynch NR, Perez M, et al. Modulation of the allergic reactivity of slum children by helminthic infection. Parasite Immunol 15:311-315, 1993.

33. Cooper PJ, Chico ME, Rodrigues LC, et al. Reduced risk of atopy among school-age children infected with geohelminth parasites in a rural area of the tropics. J Allergy Clin Immunol 111:995-1000, 2003.

34. Dodge RR, and Burrows B. The prevalence and incidence of asthma and asthma-like symptoms in a general population sample. Am Rev Respir Dis 122:567-575, 1980.

35. Broder I, Higgins MW, Mathews KP, and Keller JB. Epidemiology of asthma and allergic rhinitis in a total community, Tecumseh, Michigan. IV. Natural history. J Allergy Clin Immunol 54:100-110, 1974.

36. Bardana EJ Jr. The three " $\mathrm{s}$ ": Reform, rationing, and their repercussions on the allergist/immunologist in the United States. Ann Allergy 71:200-203, 1993. 
Copyright of Allergy \& Asthma Proceedings is the property of OceanSide Publications Inc. and its content may not be copied or emailed to multiple sites or posted to a listserv without the copyright holder's express written permission. However, users may print, download, or email articles for individual use. 